Review

\title{
The Great Masquerade: Donor-derived Infections with Uncommon Central Nervous System Pathogens
}

Amy Spallone ${ }^{1,}{ }^{*}$, Marion Hemmersbach-Miller ${ }^{1,2}$

1. Department of Medicine, Section of Infectious Diseases, Baylor College of Medicine, Houston, TX 77030, USA; E-Mails: amy.spallone@bcm.edu; Marion.Hemmersbach-Miller@bcm.edu

2. Department of Medicine, Section of Infectious Diseases, Baylor St. Luke's Medical Center, Houston, TX 77030, USA

* Correspondence: Amy Spallone; E-Mail: amy.spallone@bcm.edu

Academic Editor: Haval Shirwan

Special Issue: Organ Donation

OBM Transplantation

2021, volume 5 , issue 2

doi:10.21926/obm.transplant.2102141
Received: January 29, 2021

Accepted: April 19, 2021

Published: May 02, 2021

\begin{abstract}
Donor-derived infections (DDI) are an infrequent event in solid organ transplant (SOT) due to advances in screening recommendations, prophylaxis, and surveillance of common infections. However, unexpected pathogen transmission can still occur when a donor is not known to be infected prior to organ procurement, which can lead to significant morbidity and mortality in the organ recipient. Solid organ donors with central nervous system (CNS) pathogens are an uncommon but deadly source of unexpected DDI. Clinically recognizing these CNS infections in a potential deceased donor is enormously challenging as many are clinically silent or overshadowed by other confounding events. Because of this, expert panels caution against transplanting organs from decedents who die with possible or proven encephalitis of unknown etiology. In this review, we discuss the epidemiology, donor characteristics, and outcomes of cases of DDI in SOT recipients with unusual CNS pathogens, and provide a discussion on methods of identifying and reporting possible DDI with these pathogens.
\end{abstract}

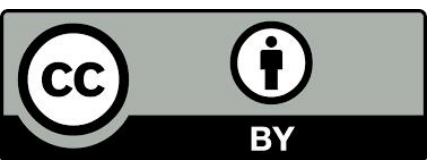

(C) 2021 by the author. This is an open access article distributed under the conditions of the Creative Commons by Attribution License, which permits unrestricted use, distribution, and reproduction in any medium or format, provided the original work is correctly cited. 


\section{Keywords}

Solid organ transplant; meningoencephalitis; central nervous system pathogens; donorderived infection

\section{Introduction}

Solid organ transplant (SOT) is considered a definitive treatment for many terminal end-organ diseases; however, demand has far outpaced supply. The number of those waiting for life-saving organ transplantation has doubled during the last two decades, while the number of transplants has only increased by $30 \%$ [1, 2]. Organs from donors with known (i.e., expected) treatable infections, or at increased risk of infections, are increasingly being utilized to offset this need [1, 3].

Donor-derived infections (DDI) are infrequent due to advances in screening recommendations, prophylaxis, and surveillance of common infections. However, unexpected pathogen transmission can still occur when a donor is not known to be infected prior to organ procurement, leading to significant morbidity and mortality $[2,4-7]$. In order to improve organ transplantation safety in the United States (U.S.), the Organ Procurement \& Transplant Network (OPTN)/ United Network for Organ Sharing (UNOS) created the Disease Transmission Advisory Group (DTAG) in 2005, later becoming the ad hoc Disease Transmission Advisory Committee (DTAC). According to data from OPTN/UNOS ad hoc DTAC, unexpected DDI are exceedingly rare, occurring in less than $0.2 \%$ of SOT recipients [8]. Such events can occur when the donor has an asymptomatic, subtle, or atypical presentation of a transmissible infection at the time of death [9]. Procedural measures may fail to capture unexpected DDI when screening is not done for geographically endemic pathogens, screening is done too early (e.g., serology fails to detect early infection), or the donor has an infection that is not routinely screened for [2,3].

Solid organ donors with central nervous system (CNS) pathogens are an uncommon but potentially deadly source of DDI [10]. During the past two decades, donor-derived CNS pathogens, such as West Nile virus (WNV), Balamuthia mandrillaris, lymphocytic choriomeningitis virus (LCMV), and rabies virus, among others, have been reported in clusters of SOT recipients [11, 12]. Clinically recognizing these CNS infections in potential deceased donors is enormously challenging as many are clinically silent, overshadowed by other confounding events (e.g., trauma, cerebral disease, or overdose), and donor information is often limited $[3,6,10]$. Overall, the lack of effective therapies, delayed recognition due to the pathogens' rarity, and the underutilization of reporting systems has resulted in devastating outcomes in SOT recipients [6, 11-13]. Because of these factors, expert panels caution against transplanting organs from decedents who die with possible or proven encephalitis of unknown etiology $[8,12,13]$.

We reviewed the published literature focusing on DDI with unusual CNS pathogens. More common forms of CNS infection (e.g., bacterial meningitis, cryptococcosis, and toxoplasmosis) are not included in this review. We discuss the epidemiology, donor characteristics, and outcomes of these challenging cases, and discuss methods of identifying and reporting possible DDI with CNS pathogens. To that end, we queried Medline, Ovid, Embase, and Web of Science using controlled 
vocabulary and natural language terms for tissue and organ donor, organ transplantation, transplant recipients, CNS disease, CNS infection, CNS trauma, encephalitis, meningitis, meningoencephalitis, donor-derived, and transplant-derived. Our literature search spanned fifty years and was limited to articles published in English. Abstracts were then manually screened by the authors to ensure that the selected publications featured cases of unexpected donor-derived infections with CNS pathogens after SOT.

\section{Viral Pathogens}

\subsection{The Arboviruses}

West Nile Virus (WNV) is a mosquito-borne Flavivirus and one of the most widely distributed arboviruses worldwide, with an area of circulation covering several continents [14, 15]. Since its emergence in North American in 1999, it has become the most common etiological agent of arboviral encephalitis in the Western Hemisphere [12]. The virus is maintained in a bird-mosquitobird life cycle and is transmitted to humans incidentally through the bite of Culex mosquitoes [12, 14,15 ]. While the majority (80\%) of infected immunocompetent individuals remain asymptomatic, up to $20 \%$ develop symptoms of fever, headache, myalgias, transient rash, and gastrointestinal symptoms [14-16]. Less than $1 \%$ develop neuroinvasive disease characterized by acute flaccid paralysis, Parkinsonian cogwheel rigidity, meningitis, encephalitis, meningoencephalitis, and asymmetric muscle weakness [14-16]. However, neuroinvasive disease may be more common in transplant recipients, where the risk from donor-derived WNV may be as high as $50 \%-75 \%$ [15-17]. During the last two decades, there have been approximately eight clusters of donor-derived WNV (Table 1), starting in 2002 when four organ recipients from a common donor developed febrile illnesses $[18,19]$. Encephalitis developed in three of the four recipients. On retrospective review of the blood products given to the donor, one unit of plasma was positive for WNV on quantitative polymerase chain reaction (PCR) $[18,19]$. Similarly, in 2008 , a heart recipient developed WNV encephalitis after transplantation from a donor who was also infected by blood products [20]. In 2005, the Center for Disease Control and Prevention (CDC) reported two SOT recipients (liver and lung) who developed neuroinvasive WNV after receiving organs from a common donor who died from a traumatic brain injury. Of the two kidney recipients, one had an asymptomatic WNV infection and the other was not infected. The donor's family revealed mosquito exposure and a febrile illness prior to death and the donor's serology demonstrated prior infection [21]. This suggests that WNV may be transmitted from a previously infected donor who mounted an immune response but likely had virus persisting in their organs. As recently as 2011, a cluster of four SOT recipients was diagnosed with donor-derived WNV from a common donor with developmental cognitive delay who developed fevers, encephalopathy, and muscle weakness prior to death $[22,23]$. No workup of possible CNS infections was performed. After WNV infection was detected in one recipient, the donor's archived clinical samples were tested, revealing WNV infection by serology and PCR [23]. Of the reported 23 SOT recipients from WNV infected donors, 21 became infected after an average of 12.4 days ( $7-20$ days) post-transplant, emphasizing the high rate of disease transmission and short duration to onset of symptoms (Table 1). While 13 survived, four died and an additional four had severe neuroinvasive disease without a reported outcome. As there is no treatment or prophylaxis of proven benefit for WNV infection, treatment largely consists of supportive care. However, several management strategies have been outlined 
in case reports [15]. The U.S. Food and Drug Administrations (FDA) has approved screening and diagnostic tests for WNV, including nucleic acid tests (NAT) and IgM serology [24]. In the U.S., blood banks screen for WNV and, in 2013, OPTN mandated that living donors be screened for WNV in endemic areas [15]. At this time, there are no established WNV screening recommendations in deceased donors. WNV should be included in the differential diagnosis of any SOT recipient with fever and neurological symptoms after transplantation when donor screening is not done. 
Table 1 Solid organ transplant transmitted cases of West Nile virus.

\begin{tabular}{|c|c|c|c|c|c|c|c|c|c|}
\hline $\begin{array}{l}\text { Cluster } \\
\text { Year, location }\end{array}$ & $\begin{array}{l}\text { Donor } \\
\text { Age/sex, } \\
\text { COD }\end{array}$ & $\begin{array}{l}\text { Donor risk- } \\
\text { factor }\end{array}$ & $\begin{array}{l}\text { Donor WNV } \\
\text { testing }\end{array}$ & $\begin{array}{l}\text { Procure } \\
\text { d organs }\end{array}$ & $\begin{array}{l}\text { Symptom } \\
\text { onset after } \\
\text { SOT (days) }\end{array}$ & $\begin{array}{l}\text { Recipient WNV } \\
\text { serum testing }\end{array}$ & $\begin{array}{l}\text { Recipient WNV } \\
\text { CSF testing }\end{array}$ & $\begin{array}{l}\text { WNV } \\
\text { Treatments }\end{array}$ & Outcomes \\
\hline \multirow{5}{*}{$\begin{array}{l}\text { 2002, Georgia } \\
\text { and Florida, } \\
\text { USA }[18,19]\end{array}$} & \multirow{5}{*}{$\begin{array}{l}20 / F \\
\text { trauma }\end{array}$} & \multirow{4}{*}{$\begin{array}{l}\text { Received } \\
\text { infected } \\
\text { blood } \\
\text { products }\end{array}$} & \multirow{5}{*}{$\begin{array}{l}\text { Serum IgM (-), } \\
\text { PCR (+), viral } \\
\text { culture (+) }\end{array}$} & Heart & 10 & PCR (+) & $\operatorname{lgM}(+)$ & None & $\begin{array}{l}\text { NI disease, } \\
\text { survived }\end{array}$ \\
\hline & & & & Liver & 7 & $\operatorname{lgM}(+)$ & Not tested & None & $\begin{array}{l}\text { WNV fever, } \\
\text { survived }\end{array}$ \\
\hline & & & & Kidney & 17 & $\lg M, \lg G(-)$ & $\begin{array}{l}\text { IgM (-), brain } \\
\text { tissue PCR, IHC, } \\
\text { viral culture (+) }\end{array}$ & None & $\begin{array}{l}\text { NI disease, } \\
\text { died }\end{array}$ \\
\hline & & & & Kidney & 14 & $\operatorname{IgM}(+)$ & $\operatorname{lgM}(+)$ & None & $\begin{array}{l}\text { NI disease, } \\
\text { survived }\end{array}$ \\
\hline & & \multirow{4}{*}{$\begin{array}{l}\text { Outdoor } \\
\text { exposure, } \\
\text { febrile } \\
\text { illness }\end{array}$} & & Liver & 13 & $\operatorname{lgM}(+)$ & $\operatorname{IgM}(+), \operatorname{PCR}(+)$ & Omr-IgG-am & $\begin{array}{l}\mathrm{NI} \text { disease, } \\
\text { coma }\end{array}$ \\
\hline \multirow{3}{*}{$\begin{array}{l}2005, \quad \text { New } \\
\text { York and } \\
\text { Pennsylvania, } \\
\text { USA [21] }\end{array}$} & \multirow{3}{*}{$\begin{array}{l}\mathrm{N} / \mathrm{A}, \\
\text { head } \\
\text { trauma }\end{array}$} & & \multirow{3}{*}{$\begin{array}{l}\text { Serum IgG (+), } \\
\operatorname{lgM}(+), \\
\operatorname{PCR}(-)\end{array}$} & Lung & 16 & $\operatorname{lgM}, \lg G(+)$ & $\lg M$ and $\lg G(+)$ & Omr-IgG-am & $\begin{array}{l}\text { NI disease, } \\
\text { coma }\end{array}$ \\
\hline & & & & Kidney $^{a}$ & - & $\operatorname{lgG}(+)$, PCR (+) & Not tested & $\begin{array}{l}\text { Omr-lgG- } \\
a m^{b}\end{array}$ & Survived \\
\hline & & & & Kidney $^{a}$ & - & $\begin{array}{l}\text { IgM, IgG, PCR (- } \\
\text { ) }\end{array}$ & Not tested & $\begin{array}{l}\text { Omr-lgG- } \\
a m^{b}\end{array}$ & Not infected \\
\hline $\begin{array}{l}2008, \\
\text { Louisiana, USA } \\
{[20,25]}\end{array}$ & $\begin{array}{l}\text { 18/M, } \\
\text { GSW } \\
\text { head }\end{array}$ & $\begin{array}{l}\text { Infected } \\
\text { blood } \\
\text { donor }\end{array}$ & $\begin{array}{l}\text { Serum IgM (-), } \\
\operatorname{IgG}(-), \operatorname{PCR}(-)\end{array}$ & Heart & 8 & $\lg M(+)$ & $\operatorname{lgM}(+)$ & $\begin{array}{l}\text { Supportive } \\
\text { care }\end{array}$ & $\begin{array}{l}\text { NI disease, } \\
\text { survived }\end{array}$ \\
\hline $\begin{array}{l}2009, \\
\text { California, } \\
\text { USA [26] }\end{array}$ & $\begin{array}{l}53 / \mathrm{M}, \\
\mathrm{ICH}\end{array}$ & $\begin{array}{l}\text { Probable } \\
\text { mosquito } \\
\text { bite }\end{array}$ & $\begin{array}{l}\text { Serum IgM (-), } \\
\text { PCR (+) }\end{array}$ & Liver & 15 & $\begin{array}{l}\operatorname{IgM}(+), \lg G(-), \\
\text { PCR (-) }\end{array}$ & $\operatorname{lgM}(+)$ & IVIG & $\begin{array}{l}\text { NI Disease, } \\
\text { survived }\end{array}$ \\
\hline
\end{tabular}




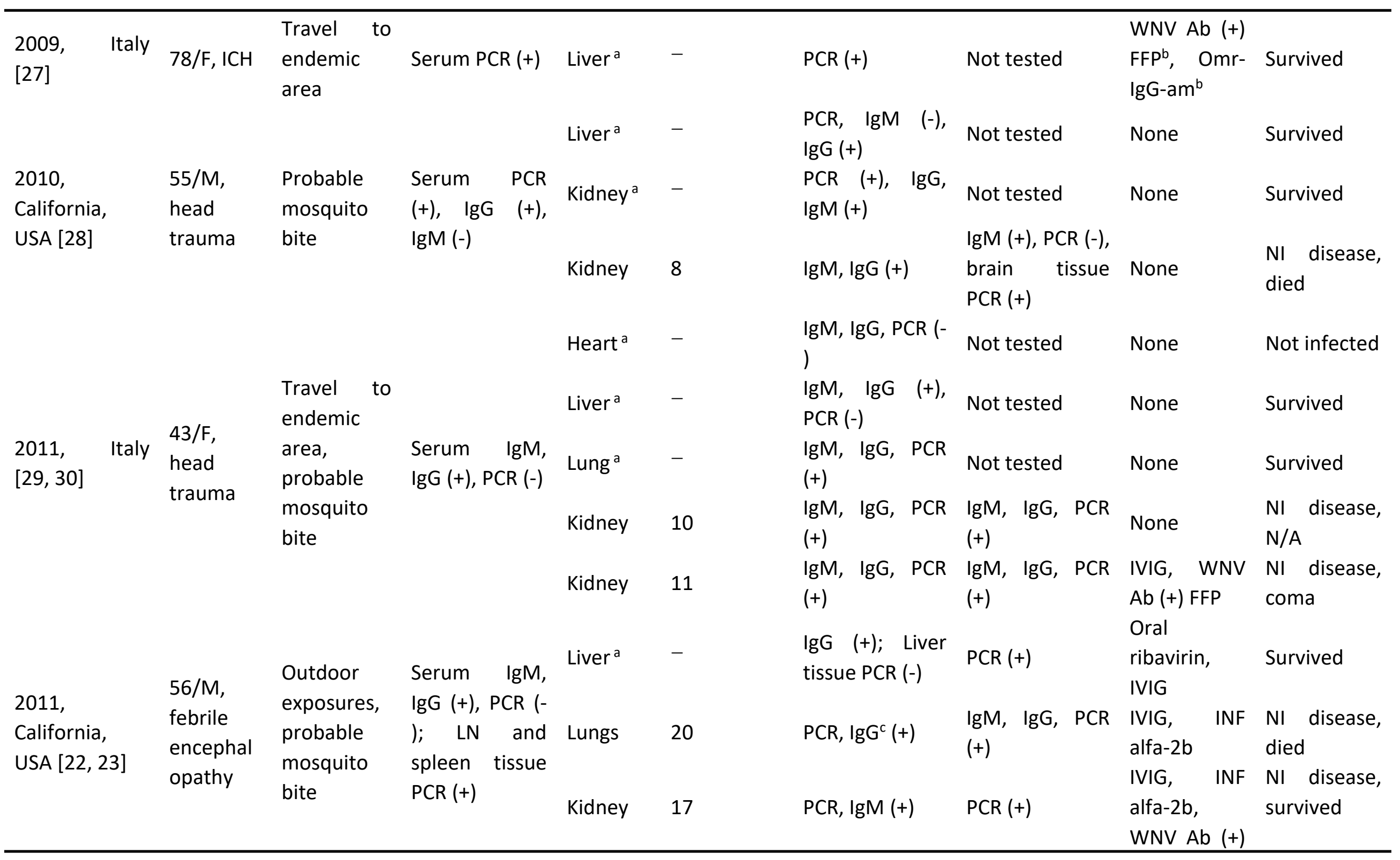




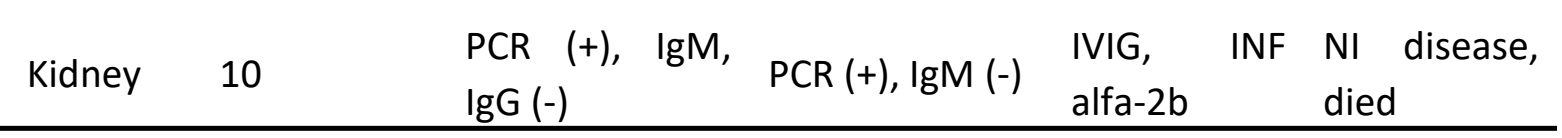

Abbreviations. COD, cause of death; SOT, solid organ transplant; CSF, cerebrospinal fluid; USA, United States of America; F, female; M, male; WNV, West Nile virus; IgM, immunoglobulin $\mathrm{M}$; IgG, immunoglobulin G; N/A, not available; PCR, polymerase chain reaction; IHC, immunohistochemistry staining; $\mathrm{NI}$, neuroinvasive; Omr-IgG-am, immune globulin with high antibody titers against WNV; GSW, gunshot wound; ICH, intracranial hemorrhage; IVIG, intravenous immunoglobulin; Ab, antibody; FFP, fresh frozen plasma; LN, lymph node; INF, interferon.

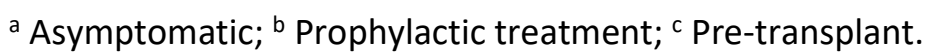


Eastern equine encephalitis virus (EEEV) is a mosquito-borne arbovirus of the genus Alphavirus that is endemic to eastern North America [14, 31]. In nature, EEEV cycles between mosquitoes and birds in forest wetlands and it incidentally infects humans through the bite of an Aedes or Culex mosquito [14, 31]. Most cases of EEEV are asymptomatic or they present with a non-specific febrile illness, with less than $<5 \%$ developing neuroinvasive disease manifesting as meningitis or encephalitis [14]. While rare, EEEV causes one of the most severe arboviral diseases in North America, with approximately $30 \%-50 \%$ case fatality, and many survivors suffer from residual neurological sequelae [14, 31, 32]. During the past two decades, the national arboviral disease surveillance system (ArboNET) has received 121 reports of human disease from 20 U.S. states, predominantly along the Atlantic and Gulf coasts [32]. To date, there has been only one published report of donor-derived EEEV [31]. In 2017, three SOT recipients (lung, heart, and liver) developed encephalitis one week after transplantation. The common donor had succumbed to a gunshot wound and had no history of febrile or neurological illness. Two of the three recipients died and the surviving recipient recovered with a residual tremor. The donor's serum was positive for EEEV RNA and all organ recipients also showed evidence of EEEV infection [14, 31]. All three SOT recipients developed neuroinvasive EEEV, suggesting a possible increased risk with donor-derived transmission. This cluster illustrates the need to consider EEEV as a cause of encephalitis in SOT recipients residing in endemic areas within the U.S.

\subsection{The Arenaviruses}

Lymphocytic choriomeningitis virus (LCMV) is an Old World arenavirus found in Europe and the Americas and is transmitted by infected rodents $[14,15]$. Infection in humans occurs through the inhalation of aerosolized excreta or saliva in dust, bites, and contact with blood from an infected rodent $[14,15]$. In immunocompetent patients, LCMV typically presents as an asymptomatic or mild self-limited febrile illness $[12,15]$. More severe cases may present as aseptic meningitis or encephalitis with very low case fatality rates $(<1 \%)$ [15]. In transplant recipients, LCMV results in severe meningoencephalitis and multisystem organ failure resulting in very high mortality rates $[12,14]$. Several clusters of SOT donor-derived LCMV infections have been reported during the last two decades (Table 2). In 2003, four SOT recipients with a common donor developed an LCMV-like infection, resulting in their deaths [33]. Laboratory testing revealed LCMV in all four SOT recipients; however, extensive donor testing revealed no LCMV. Ultimately, no source for the recipients' infection was identified [33]. Four SOT recipients were diagnosed with LCMV in 2005, three of whom died. Their infections were traced back to their donor, who died from an ischemic stroke but had contact with an asymptomatic infected pet hamster [33]. In 2008, the CDC investigated two SOT recipients with hepatic insufficiency, multiorgan failure, and death, which lead to the diagnosis of LCMV. The donor was homeless and died with an abnormal cerebrospinal fluid (CSF) analysis, emphasizing the risk that decedents with aseptic meningitis or encephalitis of unknown cause pose as donors [34]. The fourth cluster of donor-derived LCMV infections developed after the donor died from cerebral edema due to diabetic ketoacidosis. Interestingly, a corneal procurement was also performed from the donor, but no evidence of infection was ever detected in the recipient [35]. In 2013, the CDC reported a fifth cluster of SOT-derived LCMV from a donor who died from a large intracranial bleed [36]. One SOT recipient (liver) died, while the two kidney recipients survived with neurological sequelae and graft failure. A fourth cornea recipient 
remained asymptomatic [36]. Overall, a prominent clinical feature of most patients with donorderived LCMV infection is hepatitis [15]. Of the 20 SOT recipients reviewed, all become infected an average of 14.6 days (2-23 days) post-transplant (Table 2). All but five SOT recipients died as a result of their DDI. Laboratory diagnosis of LCMV is usually made by detecting IgM and IgG antibodies (CNS or serum) or by PCR or viral cultures (CNS) in a highly specialized viral pathogens laboratory (e.g., the CDC's Viral Special Pathogens Branch). LCMV as a cause of DDI is underrecognized and likely underdiagnosed because of its rarity and nonspecific clinical characteristics. It is important for transplant providers to be aware that LCMV predisposes transplant recipients to severe, often fatal, disease, while infected donors may be asymptomatic. Low provider awareness, inaccessibility of commercial diagnostic testing, and no proven effective therapies result in delayed diagnoses and subsequent poor outcomes in SOT recipients with donor-derived LCMV.

In 2008, Palacios et al. described a cluster of SOT recipients in Australia who all died of a febrile illness approximately one month post-transplant (Table 2) [37]. All three received organs from a common donor who died of a cerebral haemorrhage ten days after returning from a trip to rural former Yugoslavia. Extensive infectious diseases work-up, including PCR assays for Lyssavirus, herpes viruses 1-8, Flavivirus, Alphavirus, hantavirus, Crimean-Congo hemorrhagic fever virus, and Rift Valley fever virus, among others, were negative [37]. Multiple tissues were extracted from the SOT recipients for unbiased high-throughput sequencing, which yielded a new candidate arenavirus related to LCMV [37]. 
Table 2 Solid organ transplant transmitted cases of lymphocytic choriomeningitis virus.

\begin{tabular}{|c|c|c|c|c|c|c|c|c|c|}
\hline $\begin{array}{l}\text { Cluster } \\
\text { Year, location }\end{array}$ & $\begin{array}{l}\text { Donor } \\
\text { Age/sex, } \\
\text { COD }\end{array}$ & $\begin{array}{l}\text { Donor } \\
\text { risk-factor }\end{array}$ & $\begin{array}{l}\text { Donor LCMV } \\
\text { testing }\end{array}$ & $\begin{array}{l}\text { Organs } \\
\text { donated }\end{array}$ & $\begin{array}{l}\text { Symptom } \\
\text { onset after } \\
\text { SOT (days) }\end{array}$ & $\begin{array}{l}\text { Recipient LCMV } \\
\text { serum/tissue }^{\mathrm{a}} \\
\text { testing }\end{array}$ & $\begin{array}{l}\text { Recipient LCMV } \\
\text { CSF/CNS testing }\end{array}$ & $\begin{array}{l}\text { LCMV } \\
\text { Treatment }\end{array}$ & Outcomes \\
\hline \multirow{5}{*}{$\begin{array}{l}2003, \\
\text { Wisconsin, USA } \\
{[33]}\end{array}$} & & & \multirow{5}{*}{$\begin{array}{l}\text { Serum IgG, IgM } \\
(-) \text {; tissue IHC (- } \\
\text { ); viral culture } \\
(-)\end{array}$} & Lung & 4 & $\begin{array}{l}\lg \text {, IgG (-); } \\
\text { tissue IHC (+) }\end{array}$ & Not done & None & Died \\
\hline & & & & Liver & Early $^{b}$ & Tissue IHC (+) & Brain IHC (+) & None & Died \\
\hline & 51/M, ICH & Unknown & & Kidney & 23 & $\begin{array}{l}\text { IgG, } \operatorname{lgM}(-) \text {; } \\
\text { tissue IHC (+) }\end{array}$ & Viral culture (+) & $\begin{array}{l}\text { Cidofovir, } \\
\text { IVIG }\end{array}$ & Died \\
\hline & & & & Kidney & 22 & $\begin{array}{l}\lg (+), \operatorname{IgG}(-) ; \\
\text { tissue } \operatorname{IHC}(+) \\
\text { viral culture (+) }\end{array}$ & $\begin{array}{l}\text { Viral culture (+); } \\
\text { Brain IHC (-) }\end{array}$ & $\begin{array}{l}\text { Cidofovir, } \\
\text { IVIG }\end{array}$ & Died \\
\hline & & & & Liver & Early $^{b}$ & $\begin{array}{l}\text { Tissue IHC (+); } \\
\text { PCR (+); IgG, } \\
\lg (-)\end{array}$ & $(+)^{c}$ & None & Died \\
\hline \multirow[t]{2}{*}{$\begin{array}{l}\text { 2005, Rhode } \\
\text { Island and } \\
\text { Massachusetts, } \\
\text { USA }[33,38]\end{array}$} & $\begin{array}{l}45 / F \text {, stroke } \\
\text { and ICH }\end{array}$ & $\begin{array}{l}\text { Infected } \\
\text { pet } \\
\text { hamster }\end{array}$ & $\begin{array}{l}\text { Serum PCR (-); } \\
\text { IgG, IgM (-); } \\
\text { tissue IHC (-); } \\
\text { viral culture (-) }\end{array}$ & Lung & 3 & $\begin{array}{l}\operatorname{IgG}, \operatorname{IgM}(-) \text {; IHC } \\
(+) \text {; PCR }(+) \text {; viral } \\
\text { culture }(+)\end{array}$ & $(+)^{c}$ & None & Died \\
\hline & & & & Kidney & 17 & $\begin{array}{l}\text { Tissue IHC (+); } \\
\text { PCR (+); IgM (+), } \\
\text { IgG (-); viral } \\
\text { culture (+) }\end{array}$ & N/A & None & Died \\
\hline
\end{tabular}




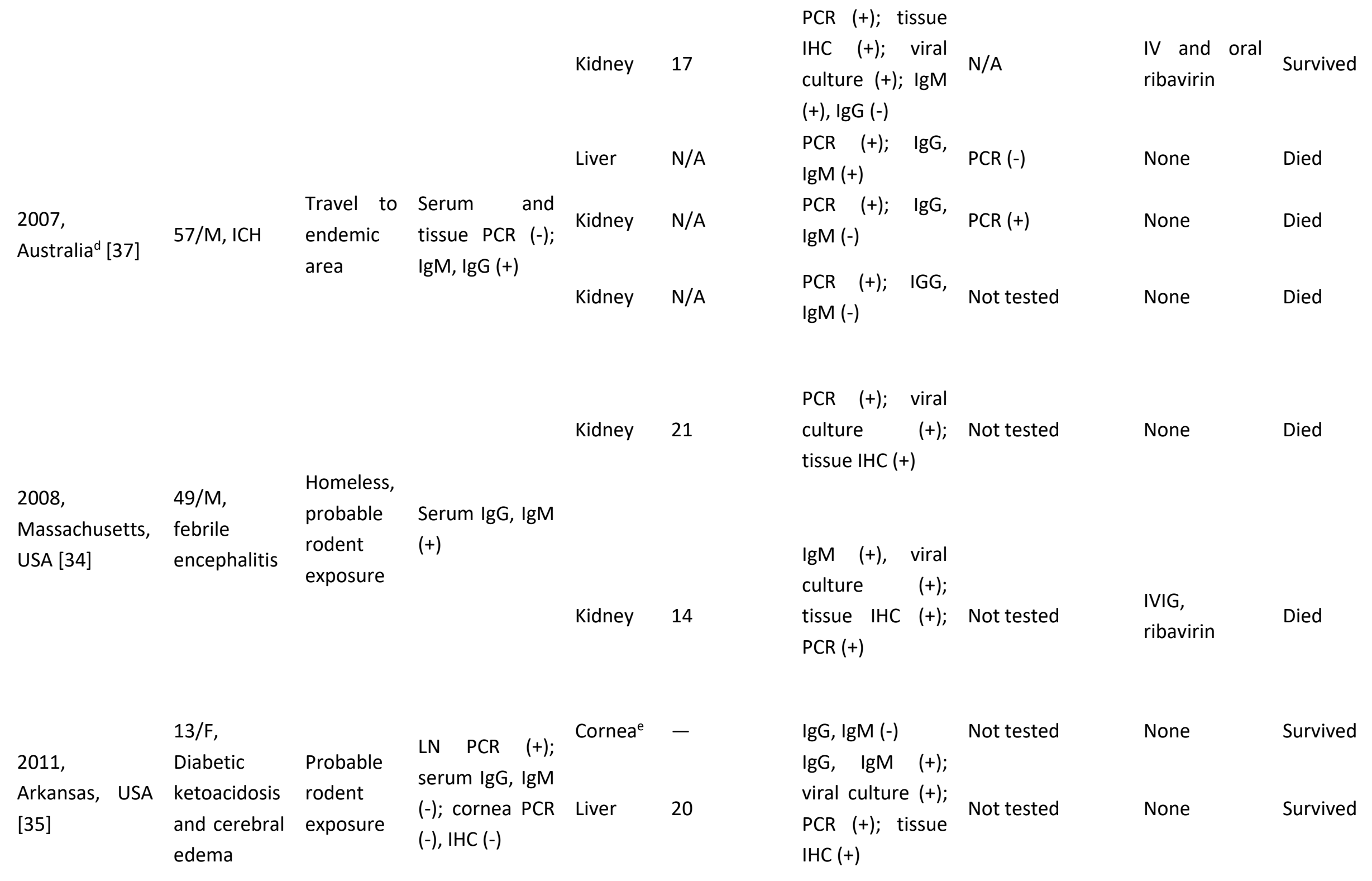




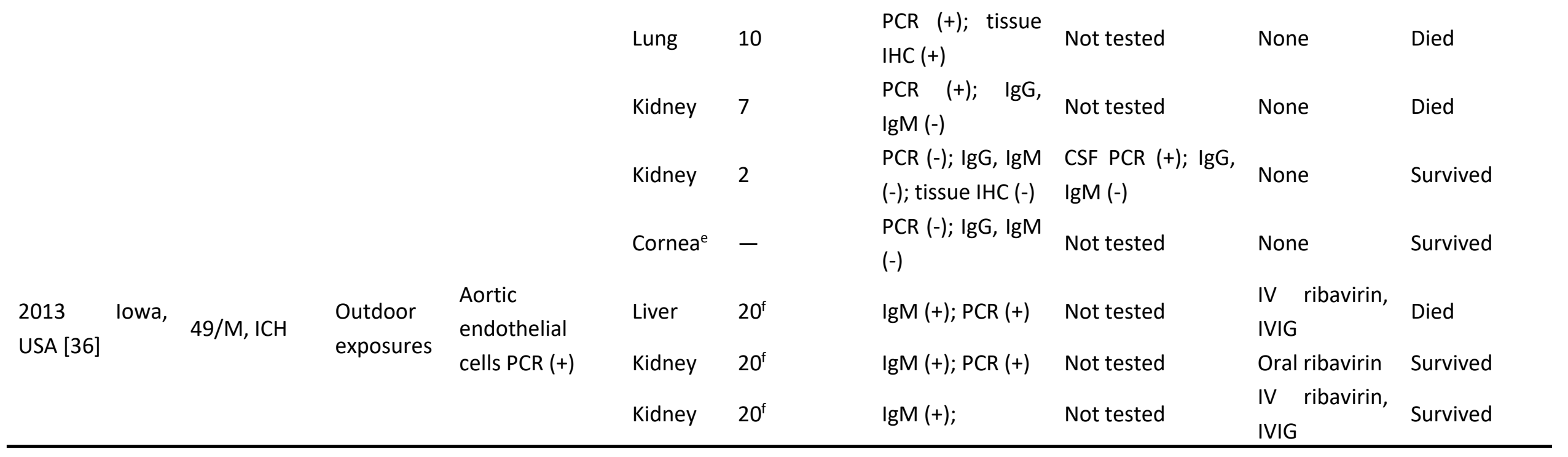

Abbreviations. COD, cause of death; LCMV, lymphocytic choriomeningitis virus; SOT, solid organ transplant; CSF, cerebrospinal fluid; CNS, central nervous system; USA, United States of America; F, female; M, male; IgM, immunoglobulin M; IgG, immunoglobulin G; IHC, immunohistochemical staining; ICH, intracranial hemorrhage; IVIG, intravenous immunoglobulin; PCR, polymerase chain reaction; IV, intravenous; N/A, not available; LN, lymph node; ${ }^{a}$ Body tissue excluding CNS tissue; ${ }^{b}$ Early unspecified - symptoms developed early post-transplant; ${ }^{\mathrm{c}}$ Test modality not specified; ${ }^{d}$ Arenavirus related to LCMV; ${ }^{\mathrm{e}}$ asymptomatic; ${ }^{\mathrm{f}}$ Approximately 20 days post-transplant. 


\subsection{Rabies Virus}

Rabies virus (RABV) is a neurotropic virus of the Lyssavirus genus with an almost worldwide distribution $[12,14]$. Human infections occur after contact with saliva from the bite or scratch of an infected animal, most commonly a bat in the U.S. Thereafter, the virus is taken up by peripheral nerves and transported over a period of weeks to months to the CNS, where it causes uniformly fatal encephalitis in the host $[12,14]$. Clinical manifestations of RABV evolve from a nonspecific prodrome of fever, malaise, and headache, followed by encephalopathy and paresthesias, and, finally, to hydrophobia, coma, and death [12]. Human-to-human transmission, which can occur through the utilization of contaminated tissues or organs (Table 3), was first described in the U.S. after a corneal transplant in 1978 and additional cases have since been reported [39-43]. Donorderived RABV after SOT was not described until 2004 when four recipients (liver, two kidneys, and arterial segment) with a common donor developed encephalitis within 30 days of transplantation [44]. Prior to death, the donor had difficulty swallowing and soon after developed fevers and encephalopathy. He was discovered to be positive for cocaine use and brain imaging demonstrated an intracranial hemorrhage. During contact tracing, it was discovered that the donor had been bitten by a bat before falling ill [44]. Another cluster of donor-derived RABV was reported soon after in Germany [42]. The donor was an otherwise healthy young female who had been bitten by a dog while traveling in India and subsequently developed encephalopathy, which progressed rapidly to respiratory distress and cardiac arrest. Brain imaging showed massive cerebral edema and CSF analysis revealed aseptic meningitis. Corneal tissue and solid organs (liver, lung, kidneys, and pancreas) were transplanted. Three of the SOT recipients developed symptoms like the donor, prompting re-examination of archived tissues and established the diagnosis of RABV. Only the liver recipient, who had been previously vaccinated against RABV 20 years earlier, survived [42]. In 2013, a deceased-donor kidney recipient was admitted for fevers, progressive extremity weakness, paresthesias, encephalopathy, and excessive salivation 17 months posttransplant [45]. He had positive RABV serologies without prior history of vaccination or animal exposure; thus, DDI was considered. Retrospective review of the donor found that he had been bitten by a racoon months before developing paresthesias, seizures, autonomic dysfunction, and death. Brain imaging was unremarkable at the time, and his CSF analysis revealed aseptic meningitis, but archived tissue analysis was positive for RABV viral RNA. The donor's other SOT recipients (right kidney, heart, and liver) received post-exposure prophylaxis and the RABV vaccine, developed neutralizing antibody response, and remained asymptomatic [45, 46]. RABV transmission through SOT has also been reported in China recently. Between 2015 and 2017, four SOT recipients were diagnosed with RABV, presumably transmitted from two donors who died from viral encephalitis of unknown etiology and acute disseminated encephalomyelitis (ADEM) [47-49]. A cluster of probable donor-derived RABV was also reported in China in 2016, which led to the death of two kidney recipients. The liver recipient from the same donor, who died of pneumonia and multi-organ failure, did not develop signs or symptoms of RABV encephalitis and was not tested for RABV [50]. Probable donor-derived RABV transmitted through SOT has also been reported recently in Kuwait $[51,52]$. Of 24 reported SOT recipients with proven or probable donor-derived RABV, 17 developed symptoms an average of 118 days (20-580 days) posttransplant and all 17 died as a result (Table 3). RABV encephalitis is uniformly fatal and, thus, 
should be considered in SOT recipients presenting with encephalitis of unknown etiology, even months after transplantation, in order to initiate post-exposure prophylaxis (i.e., human rabies immune globulin and inactivated rabies vaccine) as soon as possible in related recipients. No single RABV test is sufficient for establishing the diagnosis antemortem [53]. Highly specialized laboratories can use saliva (PCR or viral culture), serum (PCR or viral culture), CSF (antibody testing), or skin biopsies (RABV antigen) containing cutaneous nerves to detect RABV. Several of these reported cases highlight the omission of historical donor data by transplant teams and family members and emphasize the importance of having a centralized reporting system for potential DDI, such as UNOS. Considering the high rates of RABV transmission and, if unrecognized, death, potential donors with progressive neurological symptoms or encephalitis of unknown cause should be screened with extreme prejudice. 
Table 3 Solid organ transplant transmitted cases of rabies virus.

\begin{tabular}{|c|c|c|c|c|c|c|c|c|c|c|}
\hline $\begin{array}{l}\text { Clusters } \\
\text { Year, } \\
\text { location }\end{array}$ & $\begin{array}{l}\text { Donor } \\
\text { Age/sex, COD }\end{array}$ & $\begin{array}{l}\text { Donor } \\
\text { risk- } \\
\text { factor }\end{array}$ & $\begin{array}{l}\text { Donor } \\
\text { testing }\end{array}$ & RABV & $\begin{array}{l}\text { Organs } \\
\text { donated }\end{array}$ & $\begin{array}{l}\text { Symptom } \\
\text { onset after } \\
\text { SOT (days) } \\
\end{array}$ & $\begin{array}{l}\text { Recipient RABV } \\
\text { serum/tissue }^{\mathrm{a}} \\
\text { testing }\end{array}$ & $\begin{array}{l}\text { Recipient RABV } \\
\text { CSF/CNS } \\
\text { testing }\end{array}$ & $\begin{array}{l}\text { RABV } \\
\text { Treatment }\end{array}$ & $\begin{array}{l}\text { Outcome } \\
\mathrm{s}\end{array}$ \\
\hline \multirow{6}{*}{$\begin{array}{l}\text { 2004, Texas, } \\
\text { USA [44] }\end{array}$} & \multirow{5}{*}{$\begin{array}{l}\text { N/A, } \\
\text { Encephalo- } \\
\text { pathy, ICH }\end{array}$} & \multirow{5}{*}{ Bat bite } & \multirow{5}{*}{$\begin{array}{l}\text { Serum } \\
\operatorname{lgG}(+)\end{array}$} & \multirow{5}{*}{ IgM, } & Liver & Earlyb & $\begin{array}{l}\text { Tissue IHC (+); } \\
\text { IgM, IgG (+) }\end{array}$ & $\mathrm{N} / \mathrm{A}$ & None & Died \\
\hline & & & & & Kidney & Early $^{b}$ & $\begin{array}{l}\text { Tissue IHC (+); } \\
\operatorname{lgM}, \operatorname{lgg}(+)\end{array}$ & $\mathrm{N} / \mathrm{A}$ & None & Died \\
\hline & & & & & & & & EM & & \\
\hline & & & & & Kidney & Early $^{b}$ & $\begin{array}{l}\text { Tissue IHC (+); } \\
\text { IgM, IgG (-) }\end{array}$ & $\begin{array}{l}\text { rhabdovirus } \\
\text { particles; IHC } \\
(+)\end{array}$ & None & Died \\
\hline & & & & & $\begin{array}{l}\text { Arterial } \\
\text { graft }\end{array}$ & $\mathrm{N} / \mathrm{A}$ & $\begin{array}{l}\text { Tissue IHC (+); IgM } \\
(-), \lg G(+)\end{array}$ & $\mathrm{N} / \mathrm{A}$ & None & Died \\
\hline & \multirow{4}{*}{$\begin{array}{l}26 / F \text {, Aseptic } \\
\text { meningitis, } \\
\text { cerebral } \\
\text { edema }\end{array}$} & \multirow{4}{*}{$\begin{array}{l}\text { Dog bite } \\
\text { in India }\end{array}$} & \multirow{4}{*}{\multicolumn{2}{|c|}{$\begin{array}{l}\text { Brain tissue } \\
\text { EM (+) } \\
\text { rhabdovirus } \\
\text { particles and } \\
\text { DFA (+) }\end{array}$}} & Cornea ${ }^{\text {cd }}$ & - & PCR (-) & Not tested & $\begin{array}{l}\text { HRIG + RABV } \\
\text { vaccine }\end{array}$ & Survived \\
\hline \multirow{3}{*}{$\begin{array}{l}\text { 2005, } \\
\text { Germany } \\
{[42]}\end{array}$} & & & & & Liver $^{d}$ & - & $\begin{array}{l}\text { PCR } \\
\text { neutralizing } \\
(+)^{\mathrm{e}}\end{array}$ & Not tested & $\begin{array}{l}\text { HRIG + RABV } \\
\text { vaccine }\end{array}$ & Survived \\
\hline & & & & & Lung & 20 & $\begin{array}{l}\text { PCR (+); } \\
\text { culture (+) }\end{array}$ & PCR (+) & $\begin{array}{l}\text { HRIG + RABV } \\
\text { vaccine, INF-a, } \\
\text { IV ribavirin }\end{array}$ & Died \\
\hline & & & & & Kidney & 35 & PCR (+) & PCR (+) & $\begin{array}{l}\text { HRIG + RABV } \\
\text { vaccine, } \\
\text { ribavirin, INF-a, } \\
\text { amantadine }\end{array}$ & Died \\
\hline
\end{tabular}









\begin{tabular}{|c|c|c|c|c|c|c|c|c|c|c|}
\hline \multirow{5}{*}{\multicolumn{2}{|c|}{$\begin{array}{l}2017, \\
{[51]}\end{array}$}} & \multirow{4}{*}{$\begin{array}{l}\text { Male, cardio- } \\
\text { pulmonary } \\
\text { arrest }\end{array}$} & \multirow{5}{*}{$\begin{array}{l}\text { Dog bite } \\
\text { in India }\end{array}$} & \multirow{4}{*}{ N/A } & Cornea $^{\text {cd }}$ & - & $\begin{array}{l}\text { Explanted corneas } \\
\text { PCR (+) }\end{array}$ & Not tested & $\begin{array}{l}\text { HRIG + RABV } \\
\text { vaccine }\end{array}$ & Survived \\
\hline & & & & & Kidney & 3.5 months & $\operatorname{IgM}, \lg G(-)$ & Not tested & None & Died \\
\hline & & & & & Kidney & 3 months & $\mathrm{N} / \mathrm{A}$ & N/A & None & Died \\
\hline & & & & & Heart & $\mathrm{N} / \mathrm{A}$ & N/A & N/A & N/A & Died \\
\hline & & & & & Liver & $\mathrm{N} / \mathrm{A}$ & N/A & $\mathrm{N} / \mathrm{A}$ & N/A & N/A \\
\hline
\end{tabular}

Abbreviations. COD, cause of death; RABV, rabies virus; SOT, solid organ transplant; CSF, cerebrospinal fluid; CNS, central nervous system; USA, United States of America; N/A, not available; ICH, intracranial hemorrhage; EM, electron microscopy; F, female; M, male; IgM, immunoglobulin M; IgG, immunoglobulin G; IHC, immunohistochemical staining; PCR, polymerase chain reaction; DFA, direct florescence antibody; Ab, antibody; INF-a, interferon alfa; IV, intravenous; ADEM, acute disseminated encephalomyelitis; ELISA, enzyme-linked immunosorbent assay.

a Body tissue excluding CNS tissue; ${ }^{b}$ Symptoms developed within 30 days post-transplant; ${ }^{\mathrm{c}}$ Two corneas transplanted into two recipients and reported results apply to both recipients; ${ }^{d}$ Asymptomatic; ${ }^{e}$ Archived serum: patient had history of prior RABV vaccination 20 -years prior; ${ }^{\mathrm{f}}$ Probable RABV; $\mathrm{g}$ Died from pneumonia. 


\subsection{Tick-Borne Encephalitis Virus}

Tick-borne encephalitis virus (TBEV) is a tick-borne Flavivirus found throughout Europe and northern Asia, where it has become a significant health problem [14, 54]. Infection with TBEV ranges from asymptomatic to severe encephalitis and death, and diagnosis is typically confirmed by serum and CSF serology $[14,54]$. The virus is maintained in Ixodes ticks and cycles through rodents but can infect humans through either an infected tick bite or consumption of contaminated foods (e.g., raw goat's milk) in $<1 \%$ of cases [14]. Few cases of SOT-derived TBEV transmission have been reported [54]. In 2012, a cluster of donor-derived TBEV was reported in Poland, which resulted in the death of three recipients (two kidneys and liver). The same viral strain of TBEV was found in all recipients (brain tissue or CSF PCR) and the donor (brain tissue PCR), who resided in an endemic area but died as a result of trauma after a motor vehicle accident. All three recipients presented to the hospital within one-to-two months after transplantation with meningeal signs and fever [54]. Two patients in this cluster were treated with acyclovir for possible herpes encephalitis; unfortunately, there is no specific proven drug therapy for TBEV. Although rare, transplant providers should consider screening for TBEV in donors who have a history of residing or travel to areas of endemicity during warm seasons.

\section{Parasitic Pathogens}

\subsection{Primary Amebic Meningoencephalitis}

Organ procurement from SOT donors dying from a febrile encephalitis without a documented cause is frequently associated with disease transmission and, thus, should be avoided [5]. A notable exception to this is a SOT donor with proven Naegleria fowleri meningoencephalitis [5]. $N$. fowleri is a small, free-living ameba found worldwide, usually in bodies of warm water $[55,56]$. It is the etiologic agent of the devastating and rapidly fatal primary amebic meningoencephalitis (PAM), which presents with fever, headache, meningismus, and rapid neurological deterioration [55]. In 95\% of cases, death occurs within a few days of presentation [55]. In 1997, Kramer et al. reported the first case of SOT from a donor who died of undiagnosed PAM, and no subsequent infection occurred in the recipients (two kidneys and liver) despite not receiving prophylactic antiamebic therapy [56]. In 2008, organs (kidneys, pancreas, lung, and liver) from a donor known to have died from PAM were transplanted with no post-transplant infectious complications at six months [55]. Because $N$. fowleri is exclusive to the CNS and does not have systemic manifestation, transmission through organ transplantation does not occur and should not preclude organ donation $[5,55]$.

\subsection{Granulomatous Amebic Encephalitis}

Balamuthia mandrillaris is a small, free-living amebae found ubiquitously in soil worldwide and is the cause of fatal granulomatous amebic encephalitis (GAE) in humans [12, 57]. Infection is characterized by space-occupying brain lesions leading to neurological deficits [12]. Optimal treatment of GAE is not known [57]. Infection occurs through the inhalation of contaminated dust or inoculation through breaks in the skin and infection can present with skin lesions, followed months to years later by GAE [57]. Diagnosis is often made only after death; however, three tests 
can establish the diagnosis: serum indirect immunofluorescence assay (IFA), immunohistochemistry (IHC), and indirect immunofluorescence (IIF) staining [58]. Rarely, cases of SOT donor-derived GAE have been reported (Table 4) [57]. In 2009, the CDC reported cases of encephalitis among two kidney recipients from a common donor [59]. The donor was a four-yearold child who often played outdoors and who had succumbed to a subarachnoid hemorrhage following a transient febrile illness, which was diagnosed as post-influenza ADEM. Prior to death, brain imaging showed numerous small enhancing lesions and CSF analysis revealed aseptic meningitis. Post-mortem brain examination revealed $B$. mandrillaris amebae and all SOT recipients were empirically treated. One kidney recipient died despite therapy, while the other survived with significant neurological sequelae. A heart and liver recipient, who was also empirically treated, never developed signs or symptoms of GAE [59]. A second cluster of donor-derived GAE was reported by the CDC in 2010 [60]. The donor was a young male who worked in landscaping, died from a stroke, and had a notably large skin lesion on his back that had been present for six months. Two of four SOT recipients (liver, kidney, and pancreas) from this common donor developed neurological symptoms and GAE was diagnosed on brain biopsies. Despite the initiation of therapy, both recipients died, while the heart and kidney recipients remained asymptomatic after preemptive therapy [60]. It is possible that GAE is more common than thought but under-diagnosed in SOT donors with encephalitis of unknown etiology. In 2013, a third cluster was reported, involving five SOT recipients across three U.S. states from a young donor who died from traumatic head injuries [61, 62]. Diagnosis of GAE was made in the liver recipient who experienced a rapid neurologic decline and died within one month of transplantation. Multi-drug pre-emptive therapies (Table 4) were immediately started in the remaining four SOT recipients who remained asymptomatic with positive B. mandrillaris antibody titers, suggesting early diagnosis and therapeutic intervention may prevent fatal GAE [62]. Of the 12 reports of SOT recipients from donors who died with GAE, all but three were infected and four subsequently died (Table 4). Symptoms developed an average of 18.8 days (17-26 days) post-transplantation, suggesting an accelerated course in SOT recipients. 
Table 4 Solid organ transplant transmitted cases of Balamuthia mandrillaris.

\begin{tabular}{|c|c|c|c|c|c|c|c|c|c|}
\hline $\begin{array}{c}\text { Clusters } \\
\text { Year, location }\end{array}$ & $\begin{array}{l}\text { Donor } \\
\text { Age/sex, } \\
\text { COD }\end{array}$ & $\begin{array}{l}\text { Donor risk- } \\
\text { factor }\end{array}$ & $\begin{array}{l}\text { Donor } \\
\text { GAE } \\
\text { testing }\end{array}$ & $\begin{array}{l}\text { Organs } \\
\text { donated }\end{array}$ & $\begin{array}{l}\text { Symptom } \\
\text { onset after } \\
\text { SOT (days) }\end{array}$ & $\begin{array}{l}\text { Recipient GAE } \\
\text { serum/tissue }^{\mathrm{a}} \\
\text { testing }\end{array}$ & $\begin{array}{c}\text { Recipient } \\
\text { GAE CSF/CNS } \\
\text { testing }\end{array}$ & $\begin{array}{c}\text { GAE } \\
\text { Treatment }\end{array}$ & Outcomes \\
\hline \multirow{4}{*}{$\begin{array}{l}\text { 2009, Kentucky } \\
\text { and Mississippi, } \\
\text { USA }[57,59]\end{array}$} & \multirow{4}{*}{$\begin{array}{l}\text { 4/M, post- } \\
\text { influenza } \\
\text { ADEM, ICH }\end{array}$} & \multirow{4}{*}{ Soil exposure } & \multirow{4}{*}{$\begin{array}{l}\text { Brain } \\
\text { tissue IHC } \\
(+) \text {; PCR } \\
(+)\end{array}$} & Kidney & 20 & Not tested & $\begin{array}{l}\text { HP (+) } \\
\text { ameba; IHC } \\
(+) ; \text { PCR (+) }\end{array}$ & $\begin{array}{l}\text { PEN, SDZ, FLY, } \\
\text { FLC, AZT, MLF }\end{array}$ & Died \\
\hline & & & & Kidney & 20 & Not tested & $\begin{array}{l}\text { CSF PCR (+); } \\
\text { culture (+) }\end{array}$ & $\begin{array}{l}\text { PEN, SDZ, FLY, } \\
\text { FLC, AZT, MLF }\end{array}$ & Survived \\
\hline & & & & Heart $^{b}$ & - & $\begin{array}{l}\text { Serum (-); tissue }(- \\
\text { ) }\end{array}$ & $\operatorname{CSF}(-)$ & PEN, AZT, FLC & $\begin{array}{l}\text { Not } \\
\text { infected }\end{array}$ \\
\hline & & & & Liver $^{\mathrm{b}}$ & - & $\begin{array}{l}\text { Serum }(-) \text {; tissue }(- \\
\text { ) }\end{array}$ & $\operatorname{CSF}(-)$ & $\begin{array}{l}\text { PEN, AZT, FLC, } \\
\text { SDZ }\end{array}$ & $\begin{array}{l}\text { Not } \\
\text { infected }\end{array}$ \\
\hline \multirow{4}{*}{$\begin{array}{l}\text { 2010, Arizona, } \\
\text { USA }[57,60]\end{array}$} & \multirow{4}{*}{$27 / \mathrm{M}$} & \multirow{4}{*}{ Landscaper } & \multirow{4}{*}{$\begin{array}{l}\text { Ab titer } \\
(+)\end{array}$} & Liver & 17 & $\mathrm{IHC}(+)$ & $\begin{array}{l}\mathrm{IHC}(+) ; \mathrm{PCR} \\
(+)\end{array}$ & $\begin{array}{l}\text { SDZ, PYR, } \\
\text { AMB }\end{array}$ & Died \\
\hline & & & & $\begin{array}{l}\text { Kidney + } \\
\text { pancreas }\end{array}$ & 19 & IHC (-), Ab titer (+) & $\begin{array}{l}\mathrm{HP}(+) \text {; IHC } \\
(+) \text {; culture } \\
(+) ; \text { PCR (+) }\end{array}$ & $\begin{array}{l}\text { MLF, AMB, } \\
\text { ALB, FLC, AZT }\end{array}$ & Died \\
\hline & & & & Kidney $^{b}$ & - & $\begin{array}{l}\text { Tissue HP, IHC, IFA } \\
(-) ; \text { Ab titer (+) }\end{array}$ & Not tested & $\begin{array}{l}\text { PEN, FLC, AZT, } \\
M L F \\
T M P / S M Z^{c}\end{array}$ & Survived \\
\hline & & & & Heart $^{b}$ & - & $\begin{array}{l}\text { Tissue HP, IHC, IFA } \\
(-) \text {; Ab titer (-) }\end{array}$ & Not tested & $\begin{array}{l}\text { PEN, FLC, AZT, } \\
\text { SDZ, MLF }\end{array}$ & $\begin{array}{l}\text { Not } \\
\text { infected }\end{array}$ \\
\hline 2013, Alabama, & 39/M, & Homeless & Ab titer & Liver & 18 & Positive $^{d}$ & $\operatorname{CSF}(-)$ & None & Died \\
\hline
\end{tabular}




\begin{tabular}{|c|c|c|c|c|c|c|c|c|}
\hline \multirow[t]{3}{*}{$\begin{array}{l}\text { Florida, Texas, } \\
\text { USA [61] }\end{array}$} & \multirow[t]{3}{*}{ seizures } & \multirow[t]{3}{*}{$(+)$} & Kidney & - & Ab titer $(+)$ & $\operatorname{CSF}(-)$ & $\begin{array}{l}\text { MLF, AZT, } \\
\text { ALB, SDZ, FLC }\end{array}$ & Survived \\
\hline & & & Heart & - & Ab titer $(+)$ & $\operatorname{CSF}(-)$ & $\begin{array}{l}\text { MLF, AZT, } \\
\text { ALB, SDZ, FLC }\end{array}$ & Survived \\
\hline & & & $\begin{array}{c}\text { Vascular } \\
\text { graft }\end{array}$ & - & Ab titer $(+)$ & $\operatorname{CSF}(-)$ & $\begin{array}{l}\mathrm{MLF}, \mathrm{AZT} \\
\mathrm{ALB}, \mathrm{SDZ}, \mathrm{FLC}\end{array}$ & Survived \\
\hline
\end{tabular}

Abbreviations. COD, cause of death; GAE, granulomatous amebic encephalitis caused by $B$. mandrillaris; SOT, solid organ transplant; CSF, cerebrospinal fluid; CNS, central nervous system; USA, United States of America; F, female; M, male; ADEM, acute disseminated encephalomyelitis; $H P$, histopathologic tissue examination, ICH, intracranial hemorrhage; PCR, polymerase chain reaction; IHC, immunohistochemical staining; $P E N$, pentamidine; SDZ, sulfadiazine; FLY, flucytosine; FLC fluconazole; AZT, azithromycin; MLF, miltefosine; AMB, amphotericin; PYR, pyrimethamine; ALB, albendazole; TMP/SMZ, trimethoprim/sulfamethoxazole; IFA, indirect immunofluorescence assay; Ab, antibody. ${ }^{a}$ Body tissue excluding CNS tissue; ${ }^{b}$ Asymptomatic; ' Preemptive therapy; ${ }^{\mathrm{d}}$ Diagnosis of GAE made on autopsy and confirmed by CDC using unspecified specimens and tests. 


\subsection{Microsporidiosis}

Microsporidia are a diverse group of intracellular, spore-forming parasites closely related to fungi and their taxonomic classification has been heavily revised and debated numerous times [63, 64]. Fifteen microsporidian species have been identified as human pathogens, including Encephalitozoon cuniculi $[64,65]$. Based on seroprevalence data, the most common presentation of microsporidiosis may be asymptomatic disease [65]. Generally, microsporidiosis causes a spectrum of disease ranging from self-limiting gastrointestinal disease (e.g., diarrhea and malabsorption) to life-threatening disseminated infections [65]. This infection has been well characterized in HIV-infected patients; however, recently, SOT donor-derived infections have also been reported. In 2014, a kidney recipient developed headache, encephalopathy, and rapid neurologic decline and died [63]. E. cuniculi was detected by PCR in the CNS tissue of the deceased transplant recipient. Two other recipients from the common donor developed neurologic symptoms and encephalitis, but no gastrointestinal symptoms were reported and prompt initiation of treatment with albendazole led to their recovery. The three SOT recipients developed symptoms an average of 72.3 days (56-91 days) post-transplantation. The donor was a middleaged female who died after multiple endovascular repairs for arteriovenous malformations. A retrospective analysis of the donor's archived serum indicated an active $E$. cuniculi infection at the time of her death, but no gastrointestinal symptoms were reported [63]. Unlike another reported cluster of microsporidiosis after SOT [65], this cluster described donor-derived microsporidiosis infection in three SOT recipients that led to the rare presentation of disseminated neurological disease without gastrointestinal symptoms [63]. This points to a need for transplant providers to maintain awareness of microsporidiosis as a possible cause of donor-derived CNS infections in SOT recipients with encephalitis and emphasizes that prompt recognition and treatment is essential for optimal SOT-recipient outcomes.

\section{Prions}

\subsection{Transmissible Spongiform Encephalopathy}

Transmissible spongiform encephalopathy (TSE) is a general term for prion-related diseases caused by the misfolded proteins, which became well known in the 1980s due to a sudden increase in the incidence of bovine spongiform encephalopathy (BSE) or mad cow disease [66]. Creutzfeldt-Jakob disease (CJD) and variant Creutzfeldt-Jakob disease (VCJD) (i.e., BSE in humans) are rare, uniformly fatal, transmissible, neurodegenerative prion diseases with no known treatment $[66,67]$. Clinically, these diseases are characterized by progressive dementia and neuron loss, with an average latency period of 10 years [67]. While the majority of CJD has been acquired through inheritance or sporadically, numerous reports have documented its transmission through contaminated tissues, such as dura mater grafts [68] and corneas [67], among others. Between 1974 and 2006, ten cases of corneal transplant-transmitted CJD have been reported [67]. Rare reports of possible SOT-transmitted CJD have been published, including a liver recipient who died of CJD two years after transplantation [69] and a kidney recipient who died with CJD [70]. The liver recipient's donor died of a cerebral aneurysm and had no known history of neurological disease, but there was speculation that the donor received TSE-contaminated pooled plasma [69]. 
The kidney recipient's donor history was not reported, but another kidney recipient from the same donor died as well after a seizure [70]. In 2014, a retrospective study was conducted in the United Kingdom to look for organ or tissue-associated TSE but found no evidence of transplanttransmitted VCJD $[71,72]$. To date, no proven donor-derived CJD or VCJD has been reported in SOT recipients; however, transplant providers assessing transplant recipients with progressive neurologic symptoms or encephalopathy should consider donor-derived TSE as a possibility, even if rare, as the infection control concerns would be enormous. Emphasis should be placed on the use of donor registries and screening tools to detect and prevent potential TSE-containing tissues and organs.

\section{Discussion}

\subsection{Recognizing and Reporting}

Unexpected DDI are infrequent and DDI with CNS pathogens are exceedingly rare at $<0.05 \%$ of reported events [10]. Nonetheless, they account for medically important and devastating causes of DDI and poor outcomes in SOT recipients. We reviewed the published literature on DDI with rare CNS pathogens, including arboviruses (EEEV and WNC), arenaviruses (LCMV), TBEV, RABV, PAM, GAE, microsporidiosis, and prions, and we excluded more common forms of CNS infection (e.g., bacterial meningitis, cryptococcosis, and toxoplasmosis).

The clinical course and preceding events of donors are not always clearly defined and transplant providers should be aware of the risk of unexpected disease transmission in cases exhibiting "warning signs" [10]. These include young deceased donors who died with cerebral vascular accidents, seizures, or CNS imaging abnormalities, potential SOT donors who died with a febrile encephalitis of unknown cause, and potential donors who died from traumatic events with high-risk exposures. Likewise, transplant providers should maintain a high index of clinical suspicion for DDI with CNS pathogens in any SOT recipient presenting with atypical or neurological symptoms of unknown etiology. It is imperative to recognize that these pathogens often do not follow a normal timeline (i.e., incubation) and SOT recipients with DDI such as CNS pathogens can present at any time after transplantation, even years later [73].

As demonstrated by several of the cases discussed in this review, outside of routine screening, individual transplant centers and national regulations can vary in the extent of infectious disease investigation performed on potential SOT donors. Candidates should be evaluated with a thorough investigation of their medical (e.g., prior infections, vaccinations), social (e.g., drug use, sexual practices, incarceration), travel (e.g., itinerary, duration), and exposure (e.g., wild or domestic animals, occupation, areas of residence, hobbies) histories [74]. This historical data should be cross-referenced with information from donors' friends, family, or legal next-of-kin. Decisions to screen donors for the pathogens covered in this review should be driven by endemicity and their history [10]. In the U.S., OPTN/UNOS has mandated that deceased donors are tested for cytomegalovirus (CMV), Epstein-Barr virus (EBV), human immunodeficiency virus (HIV), hepatitis $B$ (HBV) and C (HCV) viruses, syphilis, and toxoplasmosis, in addition to routine cultures [74]. Testing of living donors includes CMV, EBV, HIV, HBV, Mycobacterium tuberculosis, toxoplasmosis, and syphilis. Testing for seasonal or geographical pathogens, such as WNV, Strongyloides, Coccidioides, and Chagas, should be done on a case-by-case basis based on history [74]. Lastly, reporting a potential DDI to UNOS should be completed with haste and not delayed by testing. 


\subsection{Clinical Pearls for Assessing and Reporting Donor-Derived CNS Infections}

- Any SOT recipient with post-transplant encephalitis or neurological symptoms at any time following transplantation should be worked up for possible donor-derived CNS infection.

- Any suspected donor-derived infection should be reported to the relevant OPO and national transplant authority (UNOS in the U.S.) and should not wait for test results.

- Infectious Diseases consultation and public health involvement is strongly recommended.

- Presumptive donor-derived encephalitis workup should include a detailed timeline of symptoms prior to the donor's death and history of local exposures, travel history, house-hold pet and wild animal exposures, review of complete vaccination history, hobbies, and occupation.

- Targeted testing of donor archived tissues should be completed with assistance from the CDC and the CDC's Division of High-Consequence Pathogens and Pathology (DHCPP): <https://www.cdc.gov/ncezid/dhcpp/index.html>.

\section{Conclusion}

As demonstrated in this review, recognizing potential donor-derived CNS infections is exceptionally difficult, but it is of the highest clinical importance. Thus, the OPTN's policy requires Organ Procurement Organizations (OPOs) and organ transplant hospitals in the U.S. to report any concern of a DDI transmission event to the OPTN's Patient Safety System. To assist transplant providers with the difficult task of identifying donors at high risk of transmitting CNS pathogens, the ad hoc DTAC created guidance to highlight indicators of possible at-risk donors $[8,10,75]$. This guidance also includes questions that OPOs and transplant providers should consider when completing the screening of a potential donor [75]. Utilization of such resources and careful clinical assessment, combined with a high index of suspicion, of potential SOT donors with ambiguous or confounding diagnoses will undoubtedly reduce the incidence of DDI with these often fatal CNS pathogens.

\section{Acknowledgements}

We thank Amy Sisson, medical library liaison, at the Texas Medical Center Library, Houston, TX 77030, USA, for her assistance with the literature search for this review.

\section{Author Contributions}

All authors contributed to this manuscript equally.

\section{Competing Interests}

The authors have declared that no competing interests exist.

\section{References}

1. Tullius SG, Rabb H. Improving the supply and quality of deceased-donor organs for transplantation. N Eng J Med. 2018; 378: 1920-1929.

2. Len Abad O. Infection in the process of organ donation. Rev Esp Quimioter. 2019; 32: 69-72. 
3. Kaul DR. Donor-derived infection: Epidemiology and outcomes. Curr Infect Dis Rep. 2012; 14: 676-682.

4. Garzoni C, Ison MG. Uniform definitions for donor-derived infectious disease transmissions in solid organ transplantation. Transplantation. 2011; 92: 1297-1300.

5. Ison MG, Grossi P. Donor-derived infections in solid organ transplantation. Am J Transplant. 2013; 13: 22-30.

6. Fischer SA. Is this organ donor safe?: Donor-derived infections in solid organ transplantation. Surg Clin North Am. 2019; 99: 117-128.

7. Kaul DR, Vece G, Blumberg E, La Hoz RM, Ison MG, Green M, et al. Ten years of donor-derived disease: A report of the disease transmission advisory committee. Am J Transplant. 2020; 21: 689-702.

8. Wolfe CR, Ison MG. Donor-derived infections: Guidelines from the American Society of Transplantation Infectious Diseases Community of Practice. Clin Transplant. 2019; 33: e13547.

9. Sharma TS, Michaels MG, Danziger-Isakov L, Herold BC. Clinical vignettes: Donor-derived infections. J Pediatr Infect Dis Soc. 2018; 7: S67-S71.

10. Kaul DR, Covington S, Taranto S, Green M, Lyon GM, Kusne S, et al. Solid organ transplant donors with central nervous system infection. Transplantation. 2014; 98: 666-670.

11. Kaul DR. Donor-derived infections with central nervous system pathogens after solid organ transplantation. JAMA. 2013; 310: 378-379.

12. Basavaraju SV, Kuehnert MJ, Zaki SR, Sejvar JJ. Encephalitis caused by pathogens transmitted through organ transplants, United States, 2002-2013. Emerg Infect Dis. 2014; 20: 1443-1451.

13. Smalley HK, Anand N, Buczek D, Buczek N, Lin T, Rajore T, et al. A mathematical model to describe survival among liver recipients from deceased donors with risk of transmitting infectious encephalitis pathogens. Transpl Infect Dis. 2019; 21: e13115.

14. Mrzljak A, Novak R, Pandak N, Tabain I, Franusic L, Barbic L, et al. Emerging and neglected zoonoses in transplant population. World J Transplant. 2020; 10: 47-63.

15. Anesi JA, Silveira FP. Arenaviruses and West Nile virus in solid organ transplant recipients: Guidelines from the American Society of Transplantation Infectious Diseases Community of Practice. Clin Transplant. 2019; 33: e13576.

16. Levi ME. West Nile virus infection in the immunocompromised patient. Curr Infect Dis Rep. 2013; 15: 15.

17. Kumar D, Drebot MA, Wong SJ, Lim G, Artsob H, Buck P, et al. A seroprevalence study of West Nile virus infection in solid organ transplant recipients. Am J Transplant. 2004; 4: 1883-1888.

18. Iwamoto M, Jernigan DB, Guasch A, Trepka MJ, Blackmore CG, Hellinger WC, et al. Transmission of West Nile virus from an organ donor to four transplant recipients. N Eng J Med. 2003; 348: 2196-2203.

19. Center for Disease Control and Prevention. West Nile virus infection in organ donor and transplant recipients--Georgia and Florida, 2002. MMWR Morb Mortal Wkly Rep. 2002; 51: 790.

20. Stanley E, Ratard R, Staples JE, Royce R, Bower WA, Ellingson KD, et al. West Nile virus transmission via organ transplantation and blood transfusion--Louisiana, 2008. MMWR Morb Mortal Wkly Rep. 2009; 58: 1263-1267. 
21. Center for Disease Control and Prevention. West Nile virus infections in organ transplant recipients--New York and Pennsylvania, August-September, 2005. MMWR Morb Mortal Wkly Rep. 2005; 54: 1021-1023.

22. Winston DJ, Vikram HR, Rabe IB, Dhillon G, Mulligan D, Hong JC, et al. Donor-derived West Nile virus infection in solid organ transplant recipients: Report of four additional cases and review of clinical, diagnostic, and therapeutic features. Transplantation. 2014; 97: 881-889.

23. Blau DM, Rabe IB, Bhatnagar J, Civen R, Trivedi KK, Rollin D, et al. West Nile virus RNA in tissues from donor associated with transmission to organ transplant recipients. Emerg Infect Dis. 2013 ; 19: 1518-1520.

24. U.S. Department of Health \& Human Services. Identifying Risk Factors for West Nile Virus (WNV) During Evaluation of Potential Living Donors. [cited date 2021 January 24]. Available from: https://optn.transplant.hrsa.gov/resources/guidance/identifying-risk-factors-for-WestNile-virus-wnv-during-evaluation-of-potential-living-donors/.

25. Stanley E, Ratard R, Staples JE, Royce R, Bower WA, Ellingson KD, et al. West Nile virus transmission via organ transplantation and blood transfusion-Louisiana, 2008. MMWR Morb Mortal Wkly Rep. 2009; 58: 1263-1267.

26. Rhee C, Eaton EF, Concepcion W, Blackburn BG. West Nile virus encephalitis acquired via liver transplantation and clinical response to intravenous immunoglobulin: case report and review of the literature. Transpl Infect Dis. 2011; 13: 312-317.

27. Cristina Morelli M, Sambri V, Luca Grazi G, Gaibani P, Pierro A, Cescon M, et al. Absence of neuroinvasive disease in a liver transplant recipient who acquired West Nile Virus (WNV) infection from the organ donor and who received WNV antibodies prophylactically. Clin Infect Dis. 2010; 51: e34-e37.

28. Rabe IB, Schwartz BS, Farnon EC, Josephson SA, Webber AB, Roberts JP, et al. Fatal transplantassociated West Nile virus encephalitis and public health investigation-california, 2010. Transplantation. 2013; 96: 463-468.

29. Inojosa WO, Scotton PG, Fuser R, Giobbia M, Paolin A, Maresca MC, et al. West Nile virus transmission through organ transplantation in north-eastern Italy: A case report and implications for pre-procurement screening. Infection. 2012; 40: 557-562.

30. Nanni Costa A, Capobianchi MR, Ippolito G, Palù G, Barzon L, Piccolo G, et al. West Nile virus: The Italian national transplant network reaction to an alert in the north-eastern region, Italy 2011. Euro Surveill. 2011; 16: 183-201.

31. Pouch SM, Katugaha SB, Shieh WJ, Annambhotla P, Walker WL, Basavaraju SV, et al. Transmission of eastern equine encephalitis virus from an organ donor to 3 transplant recipients. Clin Infect Dis. 2019; 69: 450-458.

32. Lindsey NP, Staples JE, Fischer M. Eastern equine encephalitis virus in the United States, 20032016. Am J Trop Med Hyg. 2018; 98: 1472-1477.

33. Fischer SA, Graham MB, Kuehnert MJ, Kotton CN, Srinivasan A, Marty FM, et al. Transmission of lymphocytic choriomeningitis virus by organ transplantation. N Eng J Med. 2006; 354: 22352249.

34. Center for Disease Control and Prevention. Brief report: Lymphocytic choriomeningitis virus transmitted through solid organ transplantation--Massachusetts, 2008. MMWR Morb Mortal Wkly Rep. 2008; 57 : 799-801. 
35. Macneil A, Ströher U, Farnon E, Campbell S, Cannon D, Paddock CD, et al. Solid organ transplant-associated lymphocytic choriomeningitis, United States, 2011. Emerg Infect Dis. 2012; 18: 1256-1262.

36. Schafer IJ, Miller R, Stroher U, Knust B, Nichol ST, Rollin PE. Notes from the field: A cluster of lymphocytic choriomeningitis virus infections transmitted through organ transplantation-lowa, 2013. MMWR Morb Mortal Wkly Rep. 2014; 63: 249.

37. Palacios G, Druce J, Du L, Tran T, Birch C, Briese T, et al. A new arenavirus in a cluster of fatal transplant-associated diseases. N Eng J Med. 2008; 358: 991-998.

38. Center for Disease Control and Prevention. Lymphocytic choriomeningitis virus infection in organ transplant recipients--Massachusetts, Rhode Island, 2005. MMWR Morb Mortal Wkly Rep. 2005; 54: 537-539.

39. Houff S, Burton R, Wilson R, Henson T, London W, Baer G, et al. Human-to-human transmission of rabies virus by corneal transplant. N Eng J Med. 1979; 300: 603-604.

40. Gode G, Bhide N. Two rabies deaths after corneal grafts from one donor. Lancet. 1988; 332: 791.

41. Javadi MA, Fayaz A, Mirdehghan SA, Ainollahi B. Transmission of rabies by corneal graft. Cornea. 1996; 15: 431-433.

42. Maier T, Schwarting A, Mauer D, Ross R, Martens A, Kliem V, et al. Management and outcomes after multiple corneal and solid organ transplantations from a donor infected with rabies virus. Clin Infect Dis. 2010; 50: 1112-1119.

43. Vetter JM, Frisch L, Drosten C, Ross RS, Roggendorf M, Wolters B, et al. Survival after transplantation of corneas from a rabies-infected donor. Cornea. 2011; 30: 241-244.

44. Srinivasan A, Burton EC, Kuehnert MJ, Rupprecht C, Sutker WL, Ksiazek TG, et al. Transmission of rabies virus from an organ donor to four transplant recipients. N Eng J Med. 2005; 352: 1103-1111.

45. Vora NM, Basavaraju SV, Feldman KA, Paddock CD, Orciari L, Gitterman S, et al. Raccoon rabies virus variant transmission through solid organ transplantation. JAMA. 2013; 310: 398407.

46. Vora NM, Orciari LA, Niezgoda M, Selvaggi G, Stosor V, Lyon III GM, et al. Clinical management and humoral immune responses to rabies post-exposure prophylaxis among three patients who received solid organs from a donor with rabies. Transpl Infect Dis. 2015; 17: 389-395.

47. Zhang J, Lin J, Tian Y, Ma L, Sun W, Zhang L, et al. Transmission of rabies through solid organ transplantation: A notable problem in China. BMC Infect Dis. 2018; 18: 273.

48. Zhang J, Lin J, Tian $Y$, Ma L, Sun $W$, Zhang L, et al. Transmission of rabies through solid organ transplant: A big issue in China. Am J Transplant. 2018; 18: 876-877.

49. Zhou H, Zhu WY, Zeng J, He JF, Liu K, Li Y, et al. Probable rabies virus transmission through organ transplantation, China, 2015. Emerg Infect Dis. 2016; 22: 1348-1352.

50. Chen SL, Zhang H, Luo ML, Chen JF, Yao D, Chen FM, et al. Rabies virus transmission in solid organ transplantation, China, 2015-2016. Emerg Infect Dis. 2017; 23: 1600-1602.

51. Saeed B, Al-Mousawi M. Rabies acquired through kidney transplantation in a child: A case report. Transplantation. 2020; 104: S378.

52. Elsiesy H, Hussain I, Abaalkhail F, Al-Hamoudi W, Elbeshbeshy H, Al Sebayel M, et al. Donor transmited rabies outbreak involving four transplant recepients in Kuwait and Saudi Arabia. Am J Transplant. 2016; 16: 695. 
53. Center for Disease Control and Prevention. Diagnosis in animals and humans [Internet]. U.S.: Center for Disease Control and Prevention.; 2011 [cited date 2021 January 24]. Available from: https://www.cdc.gov/rabies/diagnosis/animals-humans.html.

54. Lipowski D, Popiel M, Perlejewski K, Nakamura S, Bukowska-Osko I, Rzadkiewicz E, et al. A cluster of fatal tick-borne encephalitis virus infection in organ transplant setting. J Infect Dis. 2017; 215: 896-901.

55. Bennett WM, Nespral JF, Rosson MW, McEvoy KM. Use of organs for transplantation from a donor with primary meningoencephalitis due to Naegleria fowleri. Am J Transplant. 2008; 8: 1334-1335.

56. Kramer MH, Lerner CJ, Visvesvara GS. Kidney and liver transplants from a donor infected with Naegleria fowleri. J Clin Microbiol. 1997; 35: 1032-1033.

57. Farnon EC, Kokko KE, Budge PJ, Mbaeyi C, Lutterloh EC, Qvarnstrom Y, et al. Transmission of balamuthia mandrillaris by organ transplantation. Clin Infect Dis. 2016; 63: 878-888.

58. Center for Disease Control and Prevention. Diagnosis \& Detection [Internet]. U.S: Center for Disease Control and Prevention. 2019 [cited date 2021 January 25]. Available from: https://www.cdc.gov/parasites/balamuthia/diagnosis.html.

59. Schlessinger S, Kokko K, Fratkin J, Butt F, Hawxby A, Todaro M. Balamuthia mandrillaris transmitted through organ transplantation--Mississippi, 2009. MMWR Morb Mortal Wkly Rep. 2010; 59: 1165-1170.

60. Center for Disease Control and Prevention. Notes from the field: Transplant-transmitted Balamuthia mandrillaris--Arizona, 2010. MMWR Morb Mortal Wkly Rep. 2010; 59: 1182.

61. Zendejas-Ruiz IR, Gupte AA, Schain DC, Chung WK, Kulkarni RD, Eckhoff DE, et al. Balamuthia mandrillaris: An emerging pathogen in transplantation. Am J Transplant. 2013; 13: 98.

62. Gupte AA, Hocevar SN, Lea AS, Kulkarni RD, Schain DC, Casey MJ, et al. Transmission of balamuthia mandrillaris through solid organ transplantation: Utility of organ recipient serology to guide clinical management. Am J Transplant. 2014; 14: 1417-1424.

63. Smith RM, Muehlenbachs A, Schaenmann J, Baxi S, Koo S, Blau D, et al. Three cases of neurologic syndrome caused by donor-derived microsporidiosis. Emerg Infect Dis. 2017; 23: 387-395.

64. Han B, Weiss LM. Microsporidia: Obligate itracellular pathogens within the fungal kingdom. In: The fungal kingdom. 1st ed. U.S: ASM Press; 2017.

65. Hocevar SN, Paddock CD, Spak CW, Rosenblatt R, Diaz-Luna H, Castillo I, et al. Microsporidiosis acquired through solid organ transplantation: A public health investigation. Ann Intern Med. 2014; 160: 213-220.

66. Lee J, Kim SY, Hwang KJ, Ju YR, Woo HJ. Prion diseases as transmissible zoonotic diseases. Osong Public Health Res Perspect. 2013; 4: 57-66.

67. Martheswaran T, Desautels JD, Moshirfar M, Shmunes KM, Ronquillo YC, Hoopes PC. A contemporary risk analysis of iatrogenic transmission of creutzfeldt-jakob disease (CJD) via corneal transplantation in the United States. Ophthalmology Ther. 2020; 9: 465-483.

68. Ae R, Hamaguchi T, Nakamura Y, Yamada M, Tsukamoto T, Mizusawa H, et al. Update: Dura mater graft-associated creutzfeldt-jakob disease--Japan, 1975-2017. MMWR Morb Mortal Wkly Rep. 2018; 67: 274-278.

69. Créange A, Gray F, Cesaro P, Adle-Biassette H, Duvoux C, Cherqui D, et al. Creutzfeldt-jakob disease after liver transplantation. Ann Neurol. 1995; 38: 269-272. 
70. Nwadike E, Kannabhiran D, Calderon K, Salazar MN. Creutzfeldt-Jakob disease(CJD) in an adult kidney transplant patient. Am J Kidney Dis. 2014; 63: A83.

71. Molesworth A, Yates P, Hewitt P, Mackenzie J, Ironside J, Galea G, et al. vCJD associated with organ or tissue transplantation in the UK: A lookback study. Prion. 2013; 7: 60.

72. Molesworth A, Yates P, Hewitt PE, Mackenzie J, Ironside JW, Galea G, et al. Investigation of variant Creutzfeldt-Jakob disease implicated organ or tissue transplantation in the United Kingdom. Transplantation. 2014; 98: 585-589.

73. Fishman JA. Infection in solid-organ transplant recipients. N Eng J Med. 2007; 357: 2601-2614.

74. Malinis $M$, Boucher HW. Screening of donor and candidate prior to solid organ transplantation-Guidelines from the American Society of Transplantation Infectious Diseases Community of Practice. Clin Transplant. 2019; 33: e13548.

75. U.S. Department of Health \& Human Services Organ Procurement and Transplantation Network (OPTN/UNOS). Guidance for recognizing central nervous system infections in potential deceased organ donors [Internet]. 2014 [cited date 2021 January 20]. Available from: https://optn.transplant.hrsa.gov/resources/guidance/guidance-for-recognizing-centralnervous-system-infections-in-potential-deceased-organ-donors/.

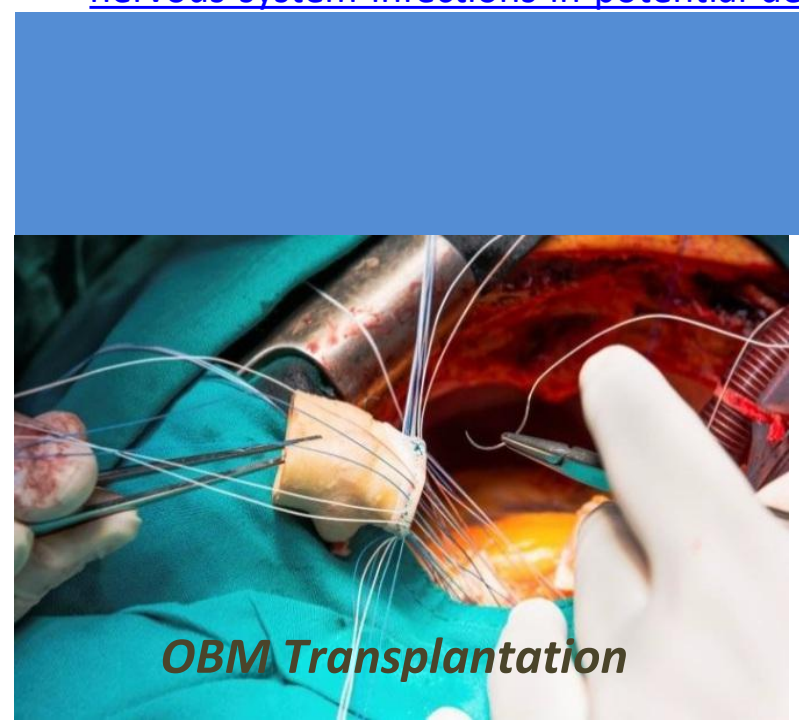

Enjoy OBM Transplantation by:

1. Submitting a manuscript

2. Joining in volunteer reviewer bank

3. Joining Editorial Board

4. Guest editing a special issue

For more details, please visit:

http://www.lidsen.com/journals/transplantation 